Special

Commentary

Marc Brownstein, DD

The late Dr. Brownstein was Chief Rabbi at the Houston Congregation for Reform Judaism. He delivered this sermon in 1992 on Yom Kippur. His wife, Barbara granted permission to publish it.

\section{Behind the Red Door}

I was the first Thanksgiving after both my parents had died, and we had come from Hartford to gather at my sister Judy's house in my hometown of Stamford, Connecticut. My youngest daughter, Gail, had never seen much of my hometown. So after dinner, I invited her to take a sentimental journey with me to visit the places where I had grown up. We drove by the old junior high, the temple where I had celebrated my Bar Mitzvah and confirmation, the Jewish Center where my childhood friends and I used to meet, and the high school from which I had graduated.

Then we were on the street where I had lived, Hillcrest Avenue. We got out of the car to walk together to the crest of the hill where my parents, Jay and Betty Brownstein, and my sister Judy and I had lived as a family. For me, as we walked up that hill, the years melted away. Suddenly, in my imagination, it was 3 PM on a day in 1950, and I was walking home from high school as I had so many years ago.

I came out of that reverie when Gail and I reached the top of the hill, standing in front of 309 Hillcrest Avenue. Almost nothing had changed. The house was still white with black shutters, and the front door was still painted red. The driveway was still covered with the same bluestone gravel, and the top of the great old chestnut tree in the back yard could still be seen above the roof of the house. Even the same old chip on the cement walk to the front door was still there.

For a fleeting, magic moment, it seemed to me that if I went to that red front door and rang the bell, Jay or Betty Brownstein would open the door. The longing in my heart to make that wonderful discovery so overwhelmed me that I began to take the first hesitant steps to ring the bell at the red door. But Gail's question, "Dad, where are you going?" brought me back to reality. Jay and Betty Brownstein were dead. Strangers now lived behind that door.

On this Yom Kippur day when many of us shall recall our beloved parents in the memorial hour of the afternoon service, I ask you these questions, questions first raised by a rabbinical colleague: What if we could go home again to a day when we could ring the bell and be greeted by our parents? What would we give for such a reunion? How could we bespeak the joy of being with them once again, the joy of talking to them again, the joy of embracing them again?

But after the tears, the laughter, the hugging — what then? What would we have to say to our parents on that miraculous day of their return? Some of us might want to say, "Mother, Father, we love you." Perhaps that was something we were never quite able to say when they were alive. Some of us might want to say, "I'm sorry." For we never found the moment to say that we regret the pain we might have caused them, or that we regret having been so wrapped up in ourselves that we were oblivious to their concerns and insensitive to their hurts and pain.

I suppose the greatest question is this: if our beloved dead, be they parents, wives, husbands, brothers, sisters, or others, could come back, would we treat them any differently than before? After the reunion, the embracing, the flood of words-after all that - would we be more patient, understanding, caring, concerned, and more sensitive than we were? Or would we again become caught up in our own lives? If they did come back, would we have learned anything?

There comes to mind the Thornton Wilder play Our Town. In it, there is for me an unforgettable scene. Emily has died at the age of 23, and, as a last request before she must cross over forever into the land of the dead, Emily asks to revisit a day in her life. She is granted permission to do it. She chooses to revisit her 12th birthday, and miraculously the images of that long-ago day pass before her. She sees herself 12 years old in the kitchen of her childhood home with her father and mother. Her father, concerned with his business problems, ignores her, and her mother, busy cooking, pays no attention to her as she tries to speak to them. Emily cries out but is unheard by the 
images before her: "Mama, Papa, look at me as if you really saw me on that day. Mama, Papa, just for a moment as we are all together, let us look at one another." But they were too preoccupied with their own concerns to really see the child in the kitchen with them, and Emily cries out as she looks upon these shades of the past, "I cannot bear it! It goes so fast and we don't have the time to look at one another." And, sobbing, she continues: "Goodbye, Mama and Papa. Do any human beings ever realize life while they live it?"

Most believe that the Memorial Service is only for those who have lost loved ones. However, this day of Memorial should mean more to those of you whose loved ones are still with you than to us who have already lost ours. It cries out to you: "Find the time to look at one another, to love one another, to be concerned for one another. Drink deeply of your beloved living before they become your beloved dead. For the day will come when they shall no longer be found behind the door."

\section{Editorial Commentary}

Rabbi Brownstein had a special talent for creating captivating, awe-inspiring sermons that were brief, thoughtprovoking, and timely. Behind the Red Door is timeless, and, I believe, his finest. Its message is powerful and moving and speaks to every living human being. For those who wish to heed its call (and all of us should), act today. Tomorrow could be too late.

Herbert L. Fred, MD, MACP,

Associate Editor,

Texas Heart Institute Journal 